\title{
Geochemistry of groundwater and saltwater intrusion in a coastal region of an island in Malacca Strait, Indonesia
}

\author{
Dewandra Bagus Eka Putra ${ }^{1^{\dagger}}$, Mohamad Sapari Dwi Hadian², Boy Yoseph CSS Syah Alam², \\ Yuniarti Yuskar, Wan Zuhairi Wan Yaacob ${ }^{3}$, Bithin Datta ${ }^{4}$, Widya Puspa Dwi Harnum ${ }^{1}$ \\ ${ }^{1}$ Department of Ceological Engineering, Universitas Islam Riau, 28284 Pekanbaru, Riau, Indonesia \\ ${ }^{2}$ Faculty of Geological Engineering, Universitas Padjadjaran, 45363, Jatinangor, Jawa Barat, Indonesia \\ ${ }^{3}$ Ceology Program, Universiti Kebangsaan Malaysia, 43600, Bangi, Selangor, Malaysia \\ ${ }^{4}$ College of Science and Engineering, James Cook University, 4814, Townsville, Queensland, Australia
}

\begin{abstract}
Most people in Bengkalis island use groundwater as their primary resource, but brackish water discovered in the wells located near the shore as well as in the distance. A hydrogeology study through geochemistry and isotope aspect conducted for the first time to identify the effect of saltwater intrusion (SWI) on groundwater. $\mathrm{Na}>\mathrm{Mg}>\mathrm{K}>\mathrm{Ca}$ were the most dominant cation sequence in groundwater, while $\mathrm{Cl}_{2}>\mathrm{HCO}_{3}$ $>\mathrm{SO}_{4}$ was the most dominant for anion. $\mathrm{NaCl}$ is the main type of groundwater in shallow aquifer and $\mathrm{NaCl} \& \mathrm{NaHCO}_{3}$ both became the most dominant type of groundwater in the deeper aquifer system. Most of the groundwater samples from dug wells indicating the weak acid exceeding strong acid. Meanwhile, the groundwater samples from bore wells dominated by alkalis exceeding alkaline earth. SWI analysis shows $36.4 \%$ of groundwater samples from dug wells and $40 \%$ of bore water samples experiencing the salinization process. From isotope analysis, the groundwater samples found to be originated from the higher elevation or distance source. Meanwhile, there are lighter $2 \mathrm{H}$ values in the samples that are indicating the groundwater flown in the deeper part of the aquifer.
\end{abstract}

Keywords: Bengkalis, Coastal groundwater, Groundwater isotope, Hydrogeochemistry, Saltwater intrusion

\section{Introduction}

The people in developing countries often had dependency to groundwater resource and thus it becomes an essential and valuable water resource [1], the number of societies facing water shortages is increasing as the level of the groundwater table decreases as a consequence of excessive usage and the level of pollution of surface and groundwater resources increases due to several anthropogenic activities [2]. For this reason, there have been many studies on water quality in various parts of the world. As a vital source of drinking water and irrigation, groundwater quality should be monitor and protect from the contaminant [3]. Groundwater in the coastal area is commonly susceptible to an environmental problem such as saltwater intrusion $[4,5]$ and upconing [6]. The salinity of water resources is a significant problem that the world population suffers. It has been studied intensively during the past decades, particularly in coastal aquifers [7]. The complexity and non-linearity of saltwater intrusion in the coastal area become a challenge [8], several reasons could explain the salinity of groundwater such as a consequence of leaching of evaporates in waterlogged areas, weathering of minerals, the movement of saline groundwater to the shallower aquifer as a result of over-pumping [9], change and variation of climate condition and rising of sea-level [10]. At this time, the coastal area facing rapid development. In several areas, the used of coastal land changed into the industrial area, which results in more problems not only for the groundwater but also seawater, especially in the area where the industrial waste has not managed improperly. Those could lead to groundwater quality problems, and even worse, the surrounding residents cannot use the resources in daily activity due to health issues [11].

Pumping test is a method to determine hydraulic properties [12], which could be used to identify the movement of the con-
This is an Open Access article distributed under the terms of the Creative Commons Attribution Non-Commercial License (http://creativecommons.org/licenses/by-nc/3.0/) which permits unrestricted non-commercial use, distribution, and reproduction in any medium, provided the original work is properly cited.

Copyright (C) 2021 Korean Society of Environmental Engineers
Received January 01, 2020 Accepted May 22, 2020

${ }^{\dagger}$ Corresponding author

Email: dewandra.bagus@eng.uir.ac.id

Tel: +62-819-5954-3306 Fax: +62-761-674-834

ORCID: 0000-0002-5095-3518 
taminant, the possibility of saltwater intrusion, and the aquifer capability as the primary source of water [13]. In addition, the electrical resistivity tomography (ERT) method could become a supporting data to model the geometry of aquifer [14] and locating contaminant [15]. This method could also detect the pathway of pollution [16] and the boundary of freshwater and saltwater from the difference of electrical current [17].

Groundwater conditions in coastal areas in Indonesia had been affected by the human, land used activity, and groundwork [18]. Seasonal differences affected the discharge volume and nutrient variations of groundwater [19]. The salinity of groundwater occurred in major cities and found to intruded the groundwater wells, both shallow and deep wells [20]. It is occurred not only on the wells that closed to the shoreline [21] but also in further sites [22]. One of the major provinces in Indonesia, Riau, has also faced saltwater intrusion and upconing problems, particularly in the coastal areas and in the islands. The study conducted in Bengkalis island (Fig. 1), located in the Malacca Strait on the east coast of Riau mainland. Initial groundwater monitoring had detected the salty water in freshwater wells as well as in the river [23]. The northern part of the study area occupied by people and there are several beaches for tourism spots, meanwhile in the land in the southern part of the study area occupied by the harbors, and populated residential area.

Stratigraphy condition of the study area (Fig. 1) based on the regional geological map from [24] was composed of Older Superficial Deposit (Qp) and Young Superficial Deposit (Qh). Older Superficial Deposits consist of clays, silts, clayey gravels, vegetation rafts, and Young Superficial Deposit consists of clays, silts, clean gravel, vegetation rafts, peat swamps [25].

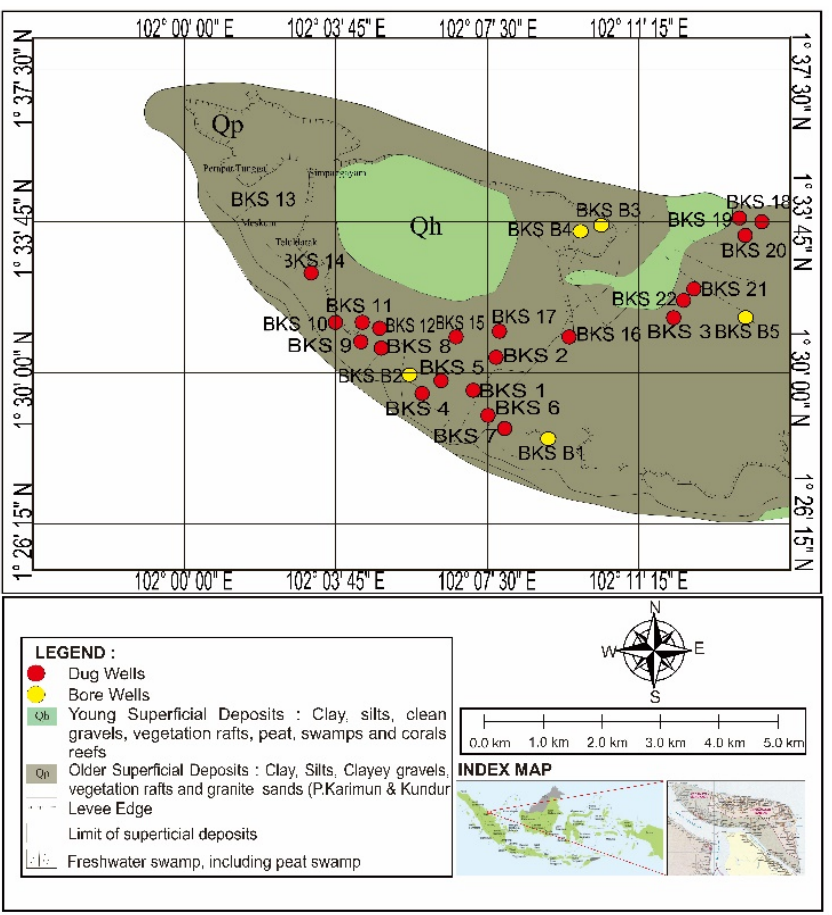

Fig. 1. Geological map of Bengkalis Island and well location map in the study area.

\section{Methodology}

Fieldwork activities consist of measuring the existing wells to obtain several data such as groundwater level, in-situ groundwater quality, and groundwater geochemistry (from water samples). Groundwater well was measured randomly both from shallow (dug) and deep wells across the island. In total, there are 22 dug wells and five bore wells (deep well) located near the coast and in the middle of the study area (Fig. 2). Five bore wells chosen by the availability of well's information (Table 1) as well as geological information of the well. The connection between dug well and bore well is the similarity of geological conditions surrounding the well.

Well's depth, electrical conductivity (EC), and total dissolved solids (TDS) were among the in-situ parameters that measured directly in the field. Water samples collected using a plastic bottle sealed with an inner cap, the bottle must be full with water so that no water bubbles inside, and preserved in the container to keep the water temperature in stable condition. The samples delivered to the Water Analytic Laboratory of National Nuclear Energy Agency (BATAN) to analyze the major ion such as $\mathrm{Na}, \mathrm{K}, \mathrm{Ca}$, $\mathrm{Mg}, \mathrm{Cl}, \mathrm{HCO}_{3}$, and $\mathrm{SO}_{4}$. Stiff and piper diagram then plotted to determine the groundwater type.

Table. 1. Information on Groundwater Well in the Study Area

\begin{tabular}{|c|c|c|c|}
\hline Well ID & $\begin{array}{l}\text { Depth } \\
\text { (m) }\end{array}$ & $\begin{array}{c}\text { Average depth of } \\
\text { water table (m) }\end{array}$ & $\begin{array}{l}\text { Distance from the } \\
\text { coast (m) }\end{array}$ \\
\hline BKS 1 & 3.3 & 2.1 & 2,250 \\
\hline BKS 2 & 1.2 & 0.8 & 740 \\
\hline BKS 3 & 2.1 & 0.8 & 1,430 \\
\hline BKS 4 & 2.9 & 0.9 & 1,720 \\
\hline BKS 5 & 4.4 & 4.2 & 2,990 \\
\hline BKS 6 & 2.7 & 2.2 & 8,860 \\
\hline BKS 7 & 3.8 & 1 & 1,390 \\
\hline BKS 8 & 1.9 & 0.4 & 1,760 \\
\hline BKS 9 & 3.2 & 1.1 & 1,150 \\
\hline BKS 10 & 3 & 3 & 1,110 \\
\hline BKS 11 & 1.6 & 1.2 & 1,210 \\
\hline BKS 12 & 2.6 & 0.1 & 1,360 \\
\hline BKS 13 & 2.5 & 0.6 & 3,180 \\
\hline BKS 14 & 3 & 1.1 & 1,300 \\
\hline BKS 15 & 1.4 & 1.2 & 4,670 \\
\hline BKS 16 & 3.5 & 1.5 & 6,820 \\
\hline BKS 17 & 2.5 & 1.9 & 5,160 \\
\hline BKS 18 & 1.9 & 0.4 & 1,280 \\
\hline BKS 19 & 1.9 & 0.4 & 1,430 \\
\hline BKS 20 & 1.2 & 0.5 & 2,820 \\
\hline BKS 21 & 3 & 1 & 5,090 \\
\hline BKS 22 & 2 & 1 & 5,460 \\
\hline BKS B1 & 115 & 60 & 2,650 \\
\hline BKS B2 & 60 & 40 & 1,580 \\
\hline BKS B3 & 54 & 40 & 2,740 \\
\hline BKS B4 & 57 & 35 & 2,940 \\
\hline BKS B5 & 81 & 60 & 2,300 \\
\hline
\end{tabular}


Saltwater intrusion analysis conducted using several methods commonly used in the previous study [26] to identified groundwater status:

a. The enrichment of Ca calculated using the formula from [27] and [28] based on the ratio of $\mathrm{Ca}$ and $\mathrm{Mg}$ concentration (in $\mathrm{mg} / \mathrm{L}$ ). High ratios $(>1)$ could be the indication of saltwater intrusion [27]

$$
\text { Ca Enrichment }=\left(\frac{\mathrm{Ca}}{\mathrm{Mg}}\right)
$$

b. [29] proposed the Simpson Ratio based on the $\mathrm{Cl}, \mathrm{HCO}_{3}$, and $\mathrm{CO}_{3}$ concentration (in $\mathrm{mg} / \mathrm{L}$ ).

$$
\text { Simpson Ratio }=\frac{\mathrm{Cl}}{\mathrm{HCO}_{3}+\mathrm{CO}_{3}}
$$

The ratio describes the contamination level and divided into five classes as shown in Table 2.

Table 2. Groundwater Classes Based on Simpson Ratio

\begin{tabular}{lc}
\hline Ratio & Quality \\
\hline$<0.5$ & Good quality \\
$0.5-1.3$ & Slightly contaminated \\
$1.3-2.8$ & Moderately contaminated \\
$2.8-6.6$ & Injuriously contaminated \\
$6.6-15.5$ & Highly contaminated \\
\hline
\end{tabular}

c. The ratio of sodium chloride (in $\mathrm{mg} / \mathrm{L}$ ) based on [27] to shows the impact on the groundwater. Saltwater intrusion impact would be shown by ratios less than 0.86 , while anthropogenic sources of contamination would be demonstrated by ratio $>1$. For the ratio value between $0.86-1$, the mean value (0.93) become the limit to determine the contamination process. If it is less than 0.93 , the contaminant source seems to be SWI. Meanwhile, if it is more than 0.93, the anthropogenic activity would be the cause of contamination.

$$
\text { Sodium Chloride Ratio }=\frac{\mathrm{Na}}{\mathrm{Cl}}
$$

d. Calculating Base Exchange Indices (BEX) proposed by [30] to distinguish if an aquifer in the salinization or freshening process.

$$
\mathrm{BEX}=\mathrm{Na}+\mathrm{K}+\mathrm{Mg}-1.0716 \mathrm{Cl}\left(\text { in } \frac{\mathrm{meq}}{\mathrm{L}}\right)
$$

Positive BEX indicates the freshening process, negative BEX indicates the salinization process, and zero value indicates no base exchange.

Stable Isotopes $\left(\delta^{2} \mathrm{H}, \delta^{2} \mathrm{O}\right)$ were analyzed using LGR Laser DLT-100. The result of stable isotopes plotted into the graph to identify the origin of the water. Interaction of groundwater-seawater traced using $\delta^{2} \mathrm{H}$ and $\delta^{2} \mathrm{O}$ isotope analysis and hydrochemical methods. Both isotopes used as a marker in identifying the source of groundwater in the aquifer, the possibility could be coming from rain, deeper or shallower groundwater, seawater, fossil water, or magmatic water ([21]; [31]). The isotope analysis in Riau province studied by [32] was the first to define the Local Meteoric Water
Line (LMWL) found that the reference value for LMWL in this area is $\delta^{2} \mathrm{H}=7.6 \delta^{18} \mathrm{O}+10.5\left(\mathrm{r}^{2}=0.921\right)$.

\section{Result and Discussion}

Hydrogeochemical analysis shows several major ions that have a significant role in the groundwater. The dominant ions found were sodium, chloride, bicarbonate, and sulfate. Carbonate analyzed, but the reagent shows no reaction indicated the absence of that ion. Table 3 shows the value for each major ion in groundwater samples.

The sequence of major ion could define the primary ions in a groundwater sample [33]. From groundwater samples that located near the coast, the cation sequences found as $\mathrm{Na}>\mathrm{Mg}>\mathrm{K}>$ $\mathrm{Ca}, \mathrm{Na}>\mathrm{Ca}>\mathrm{Mg}>\mathrm{K}$, Na $>\mathrm{Ca}>\mathrm{K}>\mathrm{Mg}$ and $\mathrm{Mg}>\mathrm{Na}$ $>\mathrm{K}>\mathrm{Ca}$, while $\mathrm{Na}>\mathrm{Ca}>\mathrm{Mg}>\mathrm{K}, \mathrm{Na}>\mathrm{Mg}>\mathrm{Ca}>\mathrm{K}$ and $\mathrm{Na}>\mathrm{Mg}>\mathrm{K}>$ Ca sequences found in the samples located in the middle of the island. In general, the most dominant cation sequence is $\mathrm{Na}>\mathrm{Mg}>\mathrm{K}>\mathrm{Ca}$ found in 11 samples.

The anion sequences found as $\mathrm{Cl}>\mathrm{HCO}_{3}>\mathrm{SO}_{4}, \mathrm{Cl}>\mathrm{SO}_{4}$ $>\mathrm{HCO}_{3}, \mathrm{HCO}_{3}>\mathrm{Cl}>\mathrm{SO}_{4}$ dan $\mathrm{SO}_{4}>\mathrm{Cl}>\mathrm{HCO}_{3}$ for water samples that located close to the coast, while $\mathrm{Cl}>\mathrm{SO}_{4}>\mathrm{HCO}_{3}$ and $\mathrm{HCO}_{3}>\mathrm{Cl}>\mathrm{SO}_{4}$ sequences found in the samples located in the middle of island. $\mathrm{Cl}>\mathrm{HCO}_{3}>\mathrm{SO}_{4}$ is the most dominant anion sequence in the study area, found in 10 samples.

\subsection{Groundwater Facies}

The concentration of each major ion plotted into Stiff diagram (Fig. 2) and Piper diagram (Fig. 3) to identify the type and facies of groundwater in the study area.

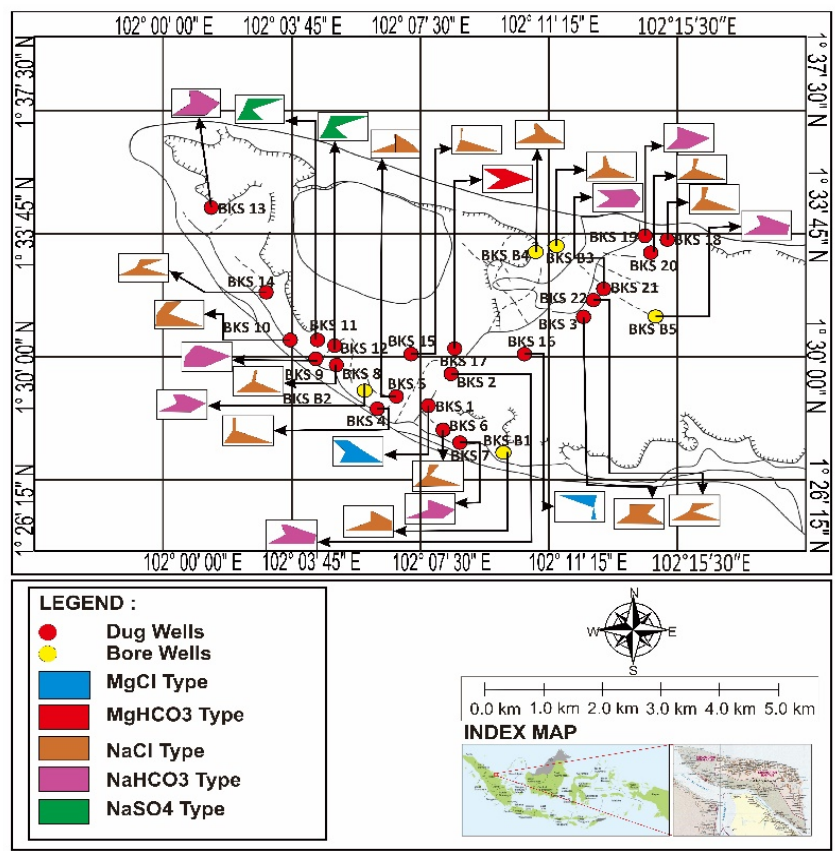

Fig. 2. Stiff diagram plot for groundwater in the study area shows the groundwater type in each location. 
Table. 3. The Concentration of Each Major Ion in Groundwater Samples

\begin{tabular}{|c|c|c|c|c|c|c|c|c|}
\hline \multirow{2}{*}{ Well ID } & \multicolumn{8}{|c|}{ Parameters (Miligram/Liter) } \\
\hline & $\mathrm{Na}$ & $\mathbf{K}$ & $\mathrm{Ca}$ & Mg & Cl & $\mathrm{HCO}_{3}$ & $\mathrm{SO}_{4}$ & $\mathrm{CO}_{3}$ \\
\hline BKS 1 & 611.80 & 51.03 & 10.51 & 85.46 & 695.04 & 579.21 & 37.73 & 0.00 \\
\hline BKS 2 & 129.85 & 8.34 & 76.80 & 5.50 & 150.73 & 41.49 & 335.82 & 0.00 \\
\hline BKS 3 & 148.08 & 16.76 & 14.02 & 24.62 & 301.46 & 73.07 & 61.48 & 0.00 \\
\hline BKS 4 & 105.65 & 6.49 & 15.45 & 22.83 & 263.83 & 41.70 & 25.56 & 0.00 \\
\hline BKS 5 & $1,046.73$ & 67.38 & 2.98 & 67.42 & $1,063.78$ & $1,160.08$ & 38.40 & 0.00 \\
\hline BKS 6 & 968.03 & 58.87 & 10.21 & 37.39 & 850.48 & $1,067.60$ & 48.76 & 0.00 \\
\hline BKS 7 & 489.54 & 20.95 & 1.05 & 20.63 & 317.75 & 607.29 & 37.98 & 0.00 \\
\hline BKS B1 & 446.88 & 21.70 & 0.75 & 20.46 & 360.33 & 603.57 & 42.06 & 0.00 \\
\hline BKS B2 & 66.37 & 11.29 & 5.21 & 12.95 & 70.55 & 154.40 & 15.89 & 0.00 \\
\hline BKS 8 & $1,041.46$ & 28.21 & 79.24 & 69.69 & $1,858.65$ & 29.72 & 156.88 & 0.00 \\
\hline BKS 9 & 32.83 & 9.00 & 12.42 & 2.75 & 25.00 & 122.02 & 12.00 & 0.00 \\
\hline BKS 10 & 33.74 & 6.62 & 13.65 & 1.88 & 58.11 & 0.00 & 20.17 & 0.00 \\
\hline BKS 11 & 16.31 & 3.25 & 6.56 & 9.15 & 15.20 & 0.00 & 56.36 & 0.00 \\
\hline BKS 12 & 18.20 & 4.19 & 13.61 & 8.20 & 13.86 & 0.00 & 94.88 & 0.00 \\
\hline BKS 13 & 330.79 & 32.86 & 2.38 & 53.79 & 304.91 & 478.89 & 46.88 & 0.00 \\
\hline BKS 14 & 47.04 & 8.58 & 17.17 & 12.05 & 62.21 & 0.00 & 134.88 & 0.00 \\
\hline BKS 15 & 5.22 & 0.46 & 0.50 & 0.50 & 7.19 & 0.00 & 4.96 & 0.00 \\
\hline BKS 16 & 4.34 & 1.10 & 0.40 & 0.83 & 6.85 & 0.00 & 3.36 & 0.00 \\
\hline BKS 17 & 139.25 & 21.24 & 1.41 & 39.85 & 113.61 & 288.16 & 41.74 & 0.00 \\
\hline BKS 18 & 78.43 & 6.07 & 11.93 & 14.22 & 193.87 & 0.00 & 46.75 & 0.00 \\
\hline BKS 19 & 908.07 & 43.99 & 106.82 & 68.44 & $1,962.23$ & 0.00 & 268.18 & 0.00 \\
\hline BKS 20 & $3,987.91$ & 155.48 & 158.48 & 545.75 & $7,271.78$ & 0.00 & 836.64 & 0.00 \\
\hline BKS 21 & 47.09 & 9.13 & 3.83 & 25.22 & 62.89 & 64.61 & 60.31 & 0.00 \\
\hline BKS 22 & 306.37 & 19.95 & 11.58 & 41.30 & 332.47 & 398.80 & 53.07 & 0.00 \\
\hline BKS B3 & 654.08 & 60.27 & 61.88 & 162.71 & $1,463.96$ & 284.24 & 50.93 & 0.00 \\
\hline BKS B4 & 679.69 & 71.92 & 55.61 & 154.72 & $1,489.74$ & 285.48 & 40.75 & 0.00 \\
\hline BKS B5 & 550.89 & 46.34 & 8.05 & 46.62 & 892.26 & 478.07 & 8.51 & 0.00 \\
\hline Maximum & $3,987.91$ & 155.48 & 158.48 & 545.75 & $7,271.78$ & $1,160.08$ & 836.64 & 0.00 \\
\hline Minimum & 4.34 & 0.46 & 0.40 & 0.50 & 6.85 & 0.00 & 3.36 & 0.00 \\
\hline Average & 477.58 & 29.31 & 26.02 & 57.59 & 748.47 & 250.31 & 95.59 & 0.00 \\
\hline
\end{tabular}

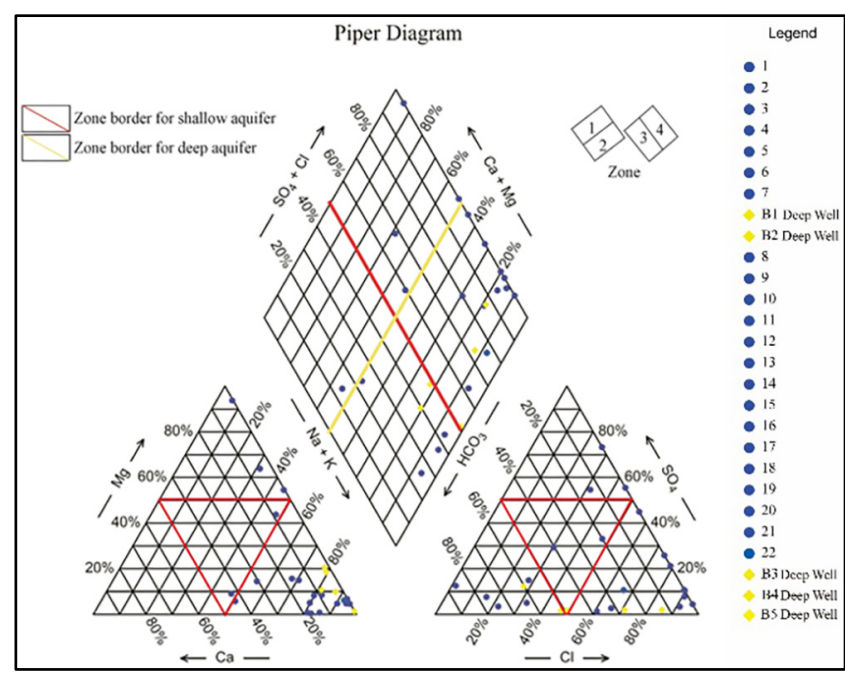

Fig. 3. Piper plot of shallow groundwater and deep groundwater samples.
Stiff diagram shows the water type based on dominant cation and anion in groundwater samples. Several water types had found, such as sodium chloride $(\mathrm{NaCl})$, sodium bicarbonate $\left(\mathrm{NaHCO}_{3}\right)$, magnesium chloride $(\mathrm{MgCl})$, magnesium sodium bicarbonate $\left(\mathrm{Mg}, \mathrm{Na}-\mathrm{K}, \mathrm{HCO}_{3}\right)$ and sodium sulfate $\left(\mathrm{NaSO}_{4}\right)$. Sodium seems to be the governing cation to determined water type from groundwater samples, and for anion, chloride became dominant ions that are ruling in the determination of water types. Fig. 3 shows the distribution of dug wells groundwater samples and the distribution of deep wells groundwater samples using Piper diagram to identify the facies and evolution of groundwater in the study area.

There are several groundwater facies determined from the cation triangle (left side), such as magnesium type, sodium or potassium type, and no dominant type (shown by red triangle). Sodium or potassium type was the dominant type of groundwater from the cation plot. From the anion triangle (right side), there are sulfate type groundwater, chloride type, bicarbonate type, and no dominant 
type (also shown by red triangle). Bicarbonate type is the most dominant type of groundwater from anion plot. The diamond diagram of Piper plot displays several groundwater facies such as calcium sulfate waters, sodium chloride waters, sodium bicarbonate waters, and calcium bicarbonate waters. The most dominant water facies is sodium bicarbonate waters found in 17 wells. In general, the shallow groundwater of the study area falls into zone 3 and zone 4 . Zone 3 indicating weak acid exceeding strong acid and zone 4 indicating strong acid exceeding weak acid.

Groundwater samples in deep wells shown to be dominated by sodium or potassium type in the cation triangle. Meanwhile, both chloride type and bicarbonate type dominated in anion triangle. In combination, the piper diamond graph indicating the domination of both sodium chloride waters and sodium bicarbonates waters. Deep wells groundwater samples fall into zone 2, which points out alkalis exceeding alkaline earth.

\subsection{Saltwater Intrusion Analysis}

Several analyses had done to determine the status of groundwater toward the saltwater intrusion phenomenon (Table 4).

\subsubsection{The enrichment of $\mathrm{Ca}$}

$36.4 \%$ of shallow groundwater samples found to be affected by the saltwater intrusion having a ratio greater than 1. It comes from BKS 2, BKS 8, BKS 9, BKS 10, BKS 12, BKS 14, BKS 15, and BKS 19 station, while the rest of samples indicating normal condition by having a ratio less than 1 . Meanwhile, the deep wells sample not yet reporting the saltwater intrusion problem.

\subsubsection{Simpson ratio}

From the calculation of chloride and bicarbonate ratio, $45.5 \%$ of shallow groundwater samples are fall into good condition category, $40.9 \%$ are in slightly contaminated, and $13.6 \%$ are in injuriously contaminated. Meanwhile, the deep groundwater samples found to be in good condition in BKS B2, slightly contaminated in BKS B1, moderately contaminated in BKS B5, and BKS B3, BKS B4 classified into injuriously contaminated state.

\subsubsection{Sodium chloride ratio}

$\mathrm{Na} / \mathrm{Cl}$ ratio indicating the source of the contaminant in groundwater. $63.6 \%$ of shallow groundwater samples contaminated by saltwater intrusion (SWI), while the other $36.4 \%$ contaminated by anthropogenic sources. Deep well groundwater samples show saltwater

Table. 4. Saltwater Intrusion Analysis for Each Groundwater Well

\begin{tabular}{|c|c|c|c|c|c|c|c|c|c|}
\hline WELL ID & $\begin{array}{c}\text { Ca } \\
\text { Enrichment }\end{array}$ & Remark & $\begin{array}{c}\text { Simpson } \\
\text { Ratio }\end{array}$ & Remark & $\begin{array}{c}\text { Sodium } \\
\text { Chloride Ratio }\end{array}$ & Remark & BEX & Remark & Overall Remark \\
\hline BKS 1 & 0.122 & Normal & 1.199 & Slightly & 0.880 & SWI & 13.861 & Freshening & More Freshening Process \\
\hline BKS 2 & 13.963 & SWI & 3.632 & Injuriously & 0.861 & SWI & 1.740 & Freshening & More SWI Process \\
\hline BKS 3 & 0.569 & Normal & 4.125 & Injuriously & 0.491 & SWI & -0.251 & Salinization & More SWI Process \\
\hline BKS 4 & 0.676 & Normal & 6.326 & Injuriously & 0.400 & SWI & -1.365 & Salinization & More SWI Process \\
\hline BKS 5 & 0.044 & Normal & 0.916 & Slightly & 0.983 & Anthropogenic & 20.524 & Freshening & More Freshening Process \\
\hline BKS 6 & 0.273 & Normal & 0.796 & Slightly & 1.138 & Anthropogenic & 20.884 & Freshening & More Freshening Process \\
\hline BKS 7 & 0.050 & Normal & 0.523 & Slightly & 1.540 & Anthropogenic & 13.886 & Freshening & More Freshening Process \\
\hline BKS 8 & 1.137 & SWI & 62.538 & Highly & 0.560 & SWI & -4.641 & Salinization & More SWI Process \\
\hline BKS 9 & 4.516 & SWI & 0.204 & Good & 1.313 & Anthropogenic & 1.126 & Freshening & More Freshening Process \\
\hline BKS 10 & 7.260 & SWI & 0.000 & Good & 0.580 & SWI & 0.028 & Freshening & More SWI Process \\
\hline BKS 11 & 0.716 & Normal & 0.000 & Slightly & 1.073 & Anthropogenic & 1.084 & Freshening & More Freshening Process \\
\hline BKS 12 & 1.659 & SWI & 0.000 & Good & 1.313 & Anthropogenic & 1.153 & Freshening & More Freshening Process \\
\hline BKS 13 & 0.044 & Normal & 0.636 & Slightly & 1.084 & Anthropogenic & 10.404 & Freshening & More Freshening Process \\
\hline BKS 14 & 1.424 & SWI & 0.000 & Good & 0.756 & SWI & 1.369 & Freshening & More SWI Process \\
\hline BKS 15 & 1.000 & SWI & 0.000 & Good & 0.726 & SWI & 0.061 & Freshening & More SWI Process \\
\hline BKS 16 & 0.481 & Normal & 0.000 & Good & 0.633 & SWI & 0.077 & Freshening & More Freshening Process \\
\hline BKS 17 & 0.035 & Normal & 0.394 & Good & 1.225 & Anthropogenic & 6.433 & Freshening & More Freshening Process \\
\hline BKS 18 & 0.838 & Normal & 0.000 & Good & 0.404 & SWI & -1.145 & Salinization & More Freshening Process \\
\hline BKS 19 & 1.560 & SWI & 0.000 & Slightly & 0.462 & SWI & -13.280 & Salinization & More SWI Process \\
\hline BKS 20 & 0.290 & Normal & 0.000 & Slightly & 0.548 & SWI & 1.700 & Freshening & More Freshening Process \\
\hline BKS 21 & 0.151 & Normal & 0.973 & Slightly & 0.748 & SWI & 2.449 & Freshening & More Freshening Process \\
\hline BKS 22 & 0.280 & Normal & 0.833 & Good & 0.921 & SWI & 7.147 & Freshening & More Freshening Process \\
\hline BKS B1 & 0.036 & Normal & 0.596 & Slightly & 1.240 & Anthropogenic & 10.744 & Freshening & More Freshening Process \\
\hline BKS B2 & 0.402 & Normal & 0.456 & Good & 0.940 & Anthropogenic & 2.100 & Freshening & More Freshening Process \\
\hline BKS B3 & 0.380 & Normal & 5.150 & Injuriously & 0.446 & SWI & -1.038 & Salinization & More SWI Process \\
\hline BKS B4 & 0.359 & Normal & 5.218 & Injuriously & 0.456 & SWI & -1.066 & Salinization & More SWI Process \\
\hline BKS B5 & 0.172 & Normal & 1.866 & Moderately & 0.617 & SWI & 1.910 & Freshening & More Freshening Process \\
\hline
\end{tabular}


intrusion contamination in BKS B3, BKS B4 and BKS B5, and anthropogenic contamination in BKS B1, BKS B2.

\subsubsection{Base exchange indices (BEX)}

Salinization or freshening process in groundwater could identify using BEX value. The positive value indicating the freshening process shown by $77.3 \%$ shallow groundwater samples, and the other $22.7 \%$ shows the salinization process, which indicating from negative $\mathrm{BEX}$ value. BKS B1, BKS B2, BKS B5 shows freshening process in deep water well, while BKS B3 and BKS B4 indicated the salinization process.

\subsubsection{Saltwater intrusion zone}

The calculation methods show differences based on the result's similarity and the relationship between the techniques. Even though in several wells indicate the disagreement of the result compares

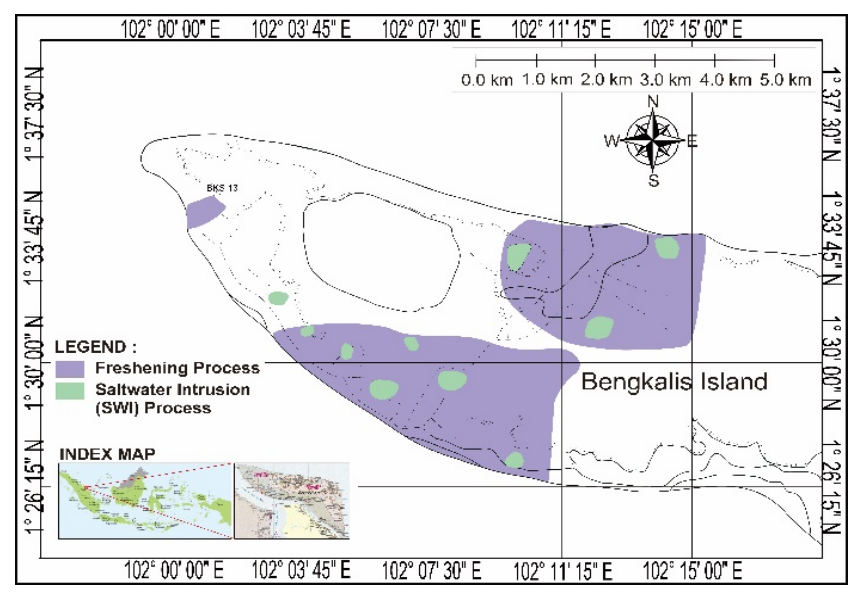

Fig. 4. The saltwater intrusion zone map in the study area shows the pattern of the saltwater intrusion zone. to one method with another, in general, all these four methods are suitable to determine the saltwater intrusion problem in groundwater samples. Saltwater intrusion process found in $36.4 \%$ shallow groundwater samples and $40 \%$ of deep groundwater samples. The saltwater intrusion zone map (Fig. 4) shows the conditions of aquifer processing in the northern part and the southern part of the study area.

Most of the process was freshening of the aquifer and some indications of contamination from anthropogenic activity. However, several wells found to experience the saltwater intrusion process The zone of intrusion likely to be upconing condition. The SWI impacted wells located in the middle of the freshening process, and the cause of this phenomenon could be excessive use of water.

\subsection{Isotope Groundwater}

Stable isotope $\delta^{2} \mathrm{H}$ and $\delta^{2} \mathrm{O}$ determined from 5 groundwater samples. They then plotted with Global Meteoric Water Line (GMWL) shown by a firm orange line and with Local Meteoric Water Line (LMWL) of Riau Province from [32] demonstrated by dash orange line.

The groundwater samples found to be in line with GMWL and LMWL, the water samples might be originated from the higher elevation or distance source. The more SWI process in the wells (Table 4) indicating the mixing of groundwater and seawater that intruded the wells, and it is an undergoing process. Meanwhile, BKS B4 and BKS B5 shown lighter $2 \mathrm{H}$ value compare to the other samples that are indicating the groundwater flown in the deeper part of the aquifer.

\section{Conclusions}

In conclusion, the result of this research found several water

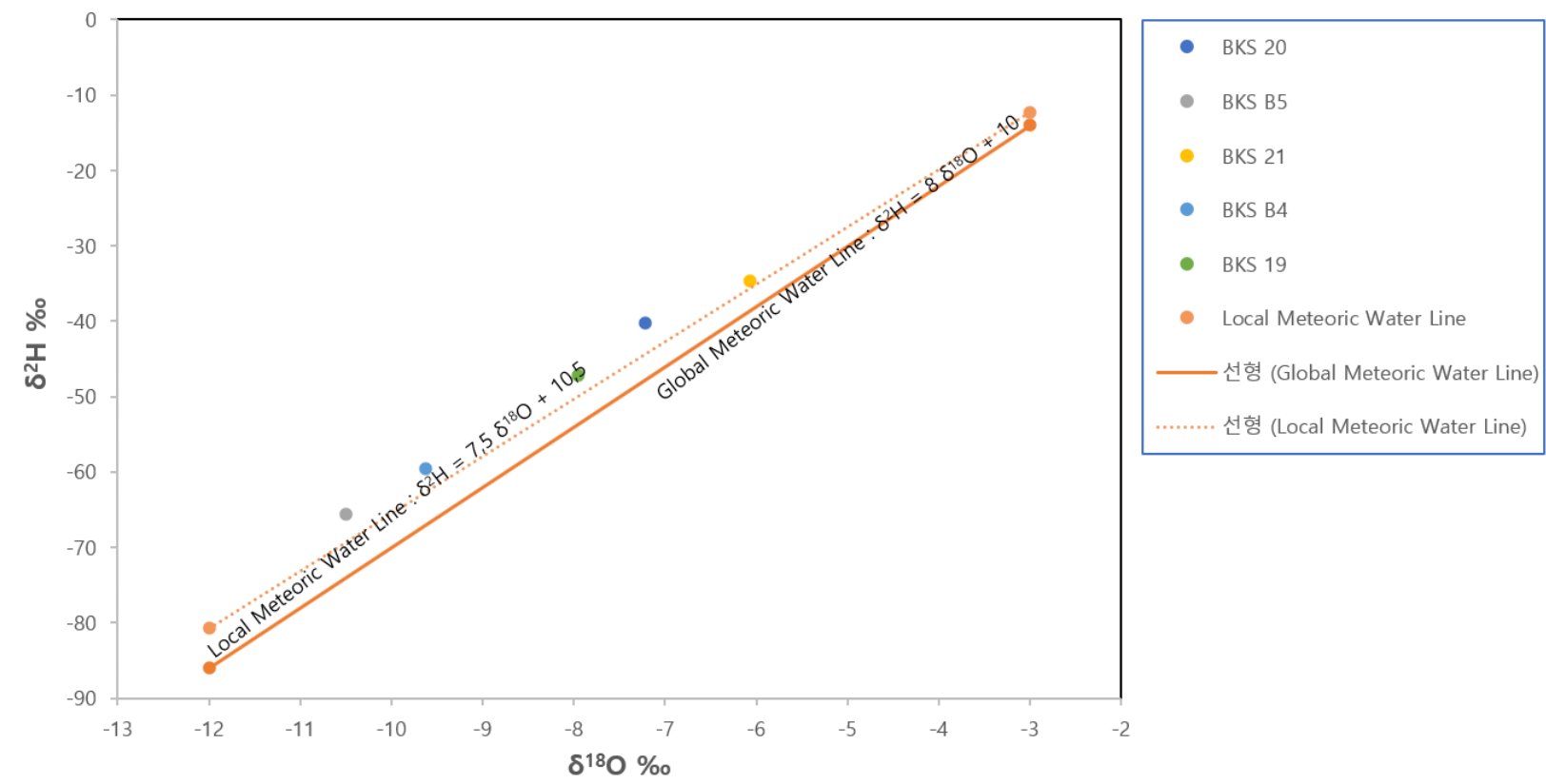

Fig. 5. Plot of groundwater isotope with global meteoric water line and local meteoric water line [32]. 
types in the study area determined from Stiff diagram, such as sodium chloride $(\mathrm{NaCl})$, sodium bicarbonate $\left(\mathrm{NaHCO}_{3}\right)$, magnesium chloride $(\mathrm{MgCl})$, magnesium sodium bicarbonate $\left(\mathrm{Mg}, \mathrm{Na}-\mathrm{K}, \mathrm{HCO}_{3}\right)$ and sodium sulfate $\left(\mathrm{NaSO}_{4}\right)$. Also, Piper diagram shows the occurrence of several groundwater facies such as calcium sulfate waters, sodium chloride waters, sodium bicarbonate waters, and calcium bicarbonate waters. The identification of the saltwater intrusion problem using four different calculations shows a similar process in each groundwater well. Most of the groundwater aquifer experienced the freshening process. However, several wells suggested the saltwater intrusion impact and the mode of intrusion likely to be an upconing process. Isotope groundwater data in some wells give the information of water origin. The groundwater found originated either from the higher elevation or distance source, and there was an indication of deeper groundwater flow in the aquifer as well. The further study of isotope groundwater needs to perform to analyze groundwater-seawater interaction.

\section{Acknowledgment}

The author shows gratitude to the Indonesia Ministry of Research and Higher Education \& Universitas Islam Riau as the funding provider for this research activity. Grant number 285/KONTRAK/ LPPM/4-2019.

\section{Author Contributions}

D.B.E.P (M.Sc) and Y.Y (M.Eng) conceived the study. D.B.E.P (M.Sc), M.S.D.H (Ph.D.), B.Y.C.S.S.S.A (Ph.D.) and W.Z.W.Y (Ph.D.) designed the research methods. D.B.E.P (M.Sc), W.P.D.H (B.Eng) and Y.Y (Ph.D.) data acquisition, M.S.D.H (Ph.D.), W.Z.W.Y (Ph.D.) and B.D (Ph.D.) provided statistical input; D.B.E.P (M.Sc), W.P.D.H (B.Eng) and B.Y.C.S.S.A (Ph.D.) data analysis, interpretation and wrote the manuscript. W.Z.W.Y (Ph.D.) and B.D (Ph.D.) provided grammatical revision to the manuscript. D.B.E.P (M.Sc) and W.P.D.H (B.Eng) provided manuscript revision.

\section{References}

1. Taufiq A, Takahiro H, Kiyoshi I, et al. Impact of excessive groundwater pumping on rejuvenation processes in the Bandung basin (Indonesia) as determined by hydrogeochemistry and modeling. Hydrog. J. 2018;26;4:281-1284.

2. Asante A, Geophrey KA, Amos TK. Assessing the vulnerability of aquifer systems in the Volta river basin: a case-study on Afram Plains, Ghana. Model Earth Syst. Environ. 2017;3;3: 1141-1159.

3. Hadian MSD, TYan W, Nana S, et al. Hydro chemistry and Characteristics of Groundwater: Case Study Water Contamination at Citarum River Upstream. J. Geosci. Eng. Environ. Technol. 2017;02;04:268-271.

4. Lal A, Bithin D. Multi-objective groundwater management strategy under uncertainties for sustainable control of saltwater intrusion: Solution for an island country in the South Pacific.
J. Environ. Manage. 2019;234:115-130.

5. Roy DK, Bithin D. A Review of Surrogate Models and Their Ensembles to Develop Saltwater Intrusion Management Strategies in Coastal Aquifers. Earth Syst. Environ. 2018;2; 2:193-211.

6. VEA Post. Fresh and saline groundwater interaction in coastal aquifers: Is our technology ready for the problems ahead? Hydrogeol. J. 2005;13;1:120-123.

7. Bahir M, Salah O, Paula MC. Geochemical and isotopic approach to decrypt the groundwater salinization origin of coastal aquifers from semi-arid areas (Essaouira basin, Western Morocco). Environ. Earth Sci. 2018;77;13:485.

8. Datta B, Harikrishna, Anirban D. Modeling and control of saltwater intrusion in a coastal aquifer of Andhra Pradesh, India. J. Hydro-environment Res. 2009;3;3:148-159.

9. Kumari R, Datta PS, Rao MS, et al. Anthropogenic perturbations induced groundwater vulnerability to pollution in the industrial Faridabad District, Haryana, India. Environ. Earth Sci. 2018;77;5:187.

10. Werner AD, Hannah KS, Sandra CG, et al. Hydrogeology and management of freshwater lenses on atoll islands: Review of current knowledge and research needs. J. Hydrol. 2017;551: 819-844.

11. Bhutiani R, Dipali BK, Dev RK. Water Quality, Pollution Source Apportionment and Health Risk Assessment of Heavy Metals in Groundwater of an Industrial Area in North India. Expo. Heal. 2016;8;1:3-18.

12. Miyake N, Nobuaki K, Akira I. Multi-aquifer pumping test to determine cutoff wall length for groundwater flow control during site excavation in Tokyo, Japan. Hydrog. J. 2008;16;5:995-1001.

13. Alam N, Olsthoorn TN. Re-evaluating the US Geological Survey's pumping tests (1967) in the Punjab region of Pakistan for use in groundwater studies. Hydrog. J. 2014;22;5:1147-1162.

14. Yeh H, Hung-I L, Chin-Shin W, et al. Electrical resistivity tomography applied to groundwater aquifer at downstream of Chih-Ben Creek basin, Taiwan. Environ. Earth Sci. 2015;3;8: 4681-4687.

15. Rehman F, Helmy SOA, Hussein MH, et al. Using a combined electrical resistivity imaging and induced polarization techniques with the chemical analysis in determining of groundwater pollution at Al Misk Lake, Eastern Jeddah, Saudi Arabia. Arab. J. Geosci. 2016;9;4:286.

16. Liao Q, Yaping D, Xiaoqing S, et al. Delineation of contaminant plume for an inorganic contaminated site using electrical resistivity tomography: comparison with direct-push technique. Environ. Monit. Assess. 2018;190;4:187.

17. Shim BO, Sang YC, Hee JK, et al. Intrinsic random function of order k kriging of electrical resistivity data for estimating the extent of saltwater intrusion in a coastal aquifer system. Environ. Geol. 2004;46;5:533-541.

18. Adyasari D, Till O, Norma A, et al. Groundwater nutrient inputs into an urbanized tropical estuary system in Indonesia. Sci. Total Environ. 2018;627:1066-1079.

19. Oehler T, Eiche E, Putra D, et al. Seasonal variability of land-ocean groundwater nutrient fluxes from a tropical karstic region (southern Java, Indonesia). J. Hydrol. 2018;565:662-671. 20. Kagabu M, Robert MD, Rachmat FL, et al. Groundwater 
Characteristics in Jakarta Area, Indonesia. Ris. Geol. dan Pertamb. 2010;20;2:69-79.

21. Satrio, Rasi P, Muhammad SDH, et al. Stable Isotopes and Hydrochemistry Approach for Determining the Salinization Pattern of Shallow Groundwater in Alluvium Deposit Semarang, Central Java. Indones. J. Geosci. 2017;4;1:1-10.

22. Wijatna AB, Kayyis M, Satrio, et al. Study of Seawater Intrusion in Deep Aquifers of Semarang Coast Using Natural Isotopes and Hydrochemicals. Indones. J. Geosci. 2019;6;1:17-28.

23. Putra DBE, Yuniarti Y, Muhammad SDH. Hydrogeology Assessment Using Physical Parameter in Bengkalis Riau. Proc. 2nd Join Conf. Utsunomiya Univ. Univ. Padjadjaran. 2017:274-279.

24. Cameron NR, Ghazali SA, Thompson SJ. Geological Map of Bengkalis, Sumatra. 1982.

25. Yuskar Y, Tiggi C, Dewandra BEP, Adi S, Rani AR. Coastal Deposit Characteristic Influenced by Terrestrial Organic Matter and Its Sedimentary Structure at Jangkang Beach, Bengkalis District, Riau Province-Indonesia. In: Proceedings of the Second International Conference on the Future of ASEAN (ICoFA) 2017; Singapore. 2018. p. 909-916.

26. Klassen J, Allen DM, Kirste D. Chemical Indicators of Saltwater Intrusion for the Gulf Islands, British Columbia. 2014.

27. Bear J, Alexander HDC, Shaul S, et al. Seawater intrusion in coastal aquifers: concepts, methods and practices, 1st ed. Boston: Kluwer Academic; 1999.

28. Moujabber MEL, Samra BB, Darwish T, et al. Comparison of Different Indicators for Groundwater Contamination by Seawater Intrusion on the Lebanese Coast. Water Resour. Manag. 2006;20;2:161-180.

29. Todd DK, Larry WM. Groundwater Hydrology. Third. United States of America: John Wiley \& Sons; 2005.

30. Stuyfzand PJ. Base exchange indices as indicators of salinization or freshening of (coastal) aquifers. In: $20^{\text {th }}$ Saltwater Intrusion Meeting; 23-27 Jun 2008; Naples. p. 262-265.

31. West AG, February EC, Bowen GJ. Spatial analysis of hydrogen and oxygen stable isotopes ('isoscapes') in ground water and tap water across South Africa. J. Geochem. Explor. 2014;145: 213-222.

32. Yuniar Y, Ari S, Ahmad S, Mohamad SdH, M Nursiyam B, Satrio S. Assuring Groundwater Safety with Stable Isotope Monitoring Method for Waste Slurry Injection Project, Duri Field, Sumatra, Indonesia. In: SPE/IATMI Asia Pacific Oil \& Gas Conference and Exhibition; 29-31 October 2019; Bali. p. 9.

33. Liu J,Dewu J, Tiantian W, et al. Hydrogeochemical processes and quality assessment of shallow groundwater in Chenqi coalfield, Inner Mongolia, China. Environ. Earth Sci. 2019;78;12:347. 